\title{
Dialogism and Carnival in Virginia Woolf's To the Lighthouse: A Bakhtinian Reading
}

\author{
Hamed Faizi \\ English Department, Faculty of Letters \& Humanities, Razi University, Kermanshah, Iran \\ E-mail: hamed.faizi89@gmail.com \\ Ali Taghizadeh (Corresponding author) \\ English Department, Faculty of Letters \& Humanities, Razi University, Kermanshah, Iran \\ E-mail: altaghee@zedat.fu-berlin.de
}

Doi:10.7575/aiac.alls.v.6n.3p.109

URL: http://dx.doi.org/10.7575/aiac.alls.v.6n.3p.109
Received: $18 / 01 / 2014$

Accepted: 29/03/2015

\begin{abstract}
Mikhail Bakhtin's dialogism in a novel promises the creation of a domain of interactive context for different voices which results in a polyphonic discourse. Instead of trying to suppress each other, the voices of the novel interact upon the other voices in a way that none of them tries to silent the other ones, and each one has the opportunity to express itself. In Virginia Woolf's To the Lighthouse, although some voices attempt to be more dominant, all are allowed to be heard and interact with the other ones. In this way Mrs. Ramsay acts like a link that helps to create a dialogic discourse by respecting the voices of all the other participants. Consequently a carnivalesque narrative discourse is established through which the voices that yield to be dominant, which is mainly Mr. Ramsay's voice, could not be established as a hierarchical position and even it loses its authoritative position as the other characters attend the dialogue in the context of the novel. The present article will take it to track the policies of dialogism and carnival in Woolf's novel and to search the production of meaning via the emergence and development of these policies. The activity in it of dialogism is the cause of unfinalizability which is the vital feature of dialogism that allows the permanent operation of dialogue upon the course of time and prevents the establishment of hierarchical positions of power. The article will also take to extrapolate the different phases in the creation of this sense of dialogism in the novel and especially highlighting the role of Mrs. Ramsay in the fabrication of such a sense.
\end{abstract}

Keywords: Bakhtin, Woolf, To the Light House, Dialogism, Carnivalesque, Unfinalizability

\section{Introduction}

Mikhail Bakhtin's theories revolve around the notion of dialogue where a person interacts with his/her outside world and this is where his/her identity and consciousness are shaped through the relationship with the other person. This is a policy of dialogism, which is "a way of looking at things that always insists on the presence of the other, on the inescapable necessity of out sidedness and unfinalizability. If Bakhtin is right, then nothing exists in itself and we live lives of buzzing, overlapping, endlessly ramifying simultaneity" (Holquist, 2002, p. 195). In Problems of Dostoyevsky's Poetics, Bakhtin declares that:

To live means to participate in dialogue: to ask questions, to heed, to respond, to agree, and so forth. In this dialogue a person participates wholly and throughout his whole life: with his eyes, lips, hands, soul, spirit, with his whole body and deeds. He invests his entire life in discourse, and this discourse enters into the dialogic fabric of human life, into the world symposium. (1984a, p. 293)

In a novel we usually observe the introduction and expansion of a variety of voices involved in the discourse, this is mainly due to the fact that "the genre of novel has the potential to include plurality of voices in it through its inherent multiple voicedness" (Nodeh, 2013, p.1). Literally speaking, dialogue refers to two persons and when more than two voices are involved in a novel we can refer to the Bakhtinian term "polyphony" which "requires three or more persons or voices and is therefore a wider concept than dialogue" (Vagaan, 2007, p. 91). Similar to dialogue, polyphony is also a narrative policy. In a novel, which is polyphonic in Bakhtinian perspective, the way characters are introduced and brought to the context actually works based on polyphony. Dentith maintains that "the whole notion of polyphony, therefore, requires careful thought both as a description of the ways novels actually work, and as an aesthetic ideal" (1995, p. 44). Hence, polyphony allows the participation of all the characters within the novel to involve in a free dialogue of expressing themselves so they can bring their ideas and existence to the scene. In a polyphonic novel we do not see the domination of only one voice, which is mainly the voice of the author; instead everybody has the right to define his/her identity in the context.

In a Bakhtinian ideally polyphonic novel, the voices inside the discourse fully respond to the presence and desires of each other. In the domain of the characters' discourse, sometimes one or more of these voices may chose to go forward in a different direction, but no voice can be excluded from the realm of negotiation. In this way, we can trace the tracks 
of the Bakhtinian theories of dialogism in Woolf's To the Lighthouse. Till the end of her narrative in this novel, the voice of each character finds many occasions to be heard, and although some voices are bolder than the others, they never fully silent them. In the creation of a realm of interactive association and mutual understanding, even the voice of an atheist like Charles Tansley, whose function seems to be a negative rivalry with that of another key character like Mrs. Ramsay, can be heard perhaps as easily as the voices of Mr. and Mrs. Ramsay and Lily Briscoe. All the characters are always in dynamic interaction while no hierarchical structure could be established. This dialogic discourse continues in the whole story which reflects the unfinalized fabric of dialogism that also paves the way for polyphony. Concerning this issue, Bakhtin states that, "this [unfinalizability] is due to the unique nature of the object itself: the novel is the sole genre that continues to develop, that is as yet uncompleted... The generic skeleton of the novel is still far from having hardened, and we cannot foresee all its plastic possibilities" (1981, p.3).

Another key notion in Bakhtinian theories, which is functional in his dialogic discourse too, is the notion of carnival. Concerning the intermingled relation between dialogue and carnival Kershner claims that, "if dialogism is the novel's proper form, carnival underlies its optimal content; the true novel is carnivalized" (2001, p. 25). According to Bakhtin, the activities in carnival creates "a boundless world of humorous forms and manifestations opposed the official and serious tone of medieval ecclesiastical and feudal culture" (1984b, p. 4). What is of primary significance in a carnival is the feature that multiple voices come together to act upon each other in a social scene in such a way that it becomes possible for every one to have his or her own voice heard, and the functioning of the hierarchies is therefore cancelled. Although such a situation works only temporarily, it gets its effects in giving the privilege to everyone to attend the carnival and simultaneously degrades the hierarchies. Carnival gives way to dialogism and cancels the functioning of the hierarchies that want to prevent a free communication among characters. Ball and Freedman also affirm this fact that, "the suspension of all hierarchical precedence during carnival time was of particular significance" (2004, p. 10). In To the Lighthouse, the author shows the voice of Mr. Ramsay perhaps excessively bold, but the continual resistance from the agents of the discourse, especially during the dinner party that Mrs. Ramsay gives, promises the formation of a widespread sense of carnival that no dimension of his existence can go out of it. The dinner party could be a direct example of carnival as each voice comes to the scene to freely express his or her thoughts and feelings. In Rabelais and His World Bakhtin writes that:

In fact, carnival does not know footlights, in the sense that it does not acknowledge any distinction between actors and spectators... Carnival is not a spectacle seen by the people; they live in it, and everyone participates because its very idea embraces all the people. While carnival lasts, there is no other life outside it. During carnival time life is subject only to its laws, that is, the laws of its own freedom. (1984b, p.7).

The project of the present paper is to analyze the notions of dialogism and carnival in Virginia Woolf's To the Lighthouse. For doing this, it will attempt to discuss the utilization in it of the free play of a dialogic discourse. And concerning carnival, it will attempt mainly to examine how Woolf's text nullifies Mr. Ramsay's authoritarian conducts for the institution of a nodal discourse where experience is not the product of dictatorial talks and gestures but of the mutual collaboration of all agents of discourse. Dialogism is well preserved till the end in an unfinalized context which does not allow the "final say" (Thomas, 2007, p. 85) to be heard from anybody. The method of our argument is mainly deductive, which we will present via a close reading on the novel. Therefore, the article tries to achieve its goals through the analysis of the role of a number of key characters in the discourse of the novel. However, we will put more emphasis on Mrs. Ramsay's role in the creation of a dialogic air in Woolf's text. The author of To the Lighthouse about a decade after 1918, still shockingly terrorized by the great massacres in World War I, is attempting symbolically to cancel all those monologic dictatorial talks as a way to help man avoid another World War, and it would be consequently ironic if readers do not find the party at Mrs. Ramsay's home a practical solution to the funk, for it is undoubtedly a functional exemplification of universal toleration through social discourse and mutual understanding.

\section{Review of Literature}

So far, To the Lighthouse has been the subject of an extensive amount of analysis from different perspectives, but this novel has not been specifically studied in the canons of Bakhtinian dialogism and carnival. A majority of the mentioned studies have focused on the feminist theories and the application of these theories on the text concerning gender and psychological status and treatment of the female characters in this novel. As an examples, Mazzuchelli points to the fact that, "the Victorian ideological model for women was the Angel in the House, a model which continued into the twentieth century and denies women their anger... Angels were expected to exude an air of pleasantry, politeness, and reverence. They were not expected to express ugly emotions such as anger" (2009, p 2). In Mazzuchelli's view Woolf is demonstrating this anger in the novel but the issue of gender is not restricted to female characters only as she continues, "anger in this novel exists on three levels: One level is Woolf's own anger towards the patriarchy; the second level is anger expressed by the male characters; and the third level is Mrs. Ramsay's anger" (ibid). Also Gjurgjang writes, "consequently, To the Lighthouse, though predominantly a female novel, delineates the process of maturation through the father-son relationship. The journey to the lighthouse symbolizes James's initiation into manliness as he steers the boat to its final destination" (2010, p 3). Character development and scrutiny of characters of the novel, especially Mrs. Ramsay and Lily Briscoe, have been also the center of attention among literary critics. For example, concerning character development Miller emphasizes that, "Very little about Woolf's writing was linear, including... her writing development" (2011, p.6). What is important for her is the unconventional and un-linear way that characters develop in Woolf's novel. The characters' policies toward each other is of primary importance in this case. 
Perhaps we can agree to some extent with the Woolf's portrayal of the marginalized role of women in her discourse, but it has to be said that this analysis is going to analyze different character, regardless of their gender from a Bakhtinian point of view. Besides, we already saw that there are also male characters who are detested and marginalized like Charles Tansley. Bakhtinian reading covers a vast area and we are talking about the nature of character marginalization and efforts to create a dialogic air in different situations. We are also going to scrutinize character development and the fact that different types of characters learn how to tolerate each in a dialogic background concerning the notion of unfinalizability.

\section{Discussion and Analysis}

\subsection{Dialogism}

In Woolf's To the Lighthouse, different types of characters come together in the summer house of the Ramsay family. But these characters are not of a same personality. They neither show a same conduct, nor do they speak in a same speech. Instead, they show a wide range of behaviors and attitudes, and speak in as wide a range of different professions. Woolf has given this chance to her characters to express themselves in different ways with so much elaboration. Bakhtin elaborates on this feature of dialogism in Speech Genres and Other Late Essays by asserting that, "each rejoinder, regardless of how brief and abrupt, has a specific quality of completion that expresses a particular position of the speaker, to which one may respond or assume, with respect to it, a responsive position" (1986, p. 72). In this novel, the author actually tries to show us that everybody has his or her own point of view in collaboration with the outside world.

To achieve this goal, Woolf employs Mrs. Ramsay to play the vital role of a linking agent among the characters, to the extent that after her death in the second chapter, everything comes to be apparently ruptured. In the third chapter, she puts this feeling into words in the consciousness of Lily Briscoe:

As if the link that usually bound things together had been cut, and they floated up here, down there, off, anyhow. How aimless it was, how chaotic, how unreal it was, she thought, looking at her empty coffee cup. Mrs. Ramsay dead; Andrew killed; Prue dead too - repeat it as she might, it roused no feeling in her. (Woolf, 1994, p.110):

Even if Mrs. Ramsay can occasionally loathe other characters, she tries to respect them. For example, Charles Tansley is an annoying guy who has teased James more than once because of which she may detest him; "she looked at him. He was such a miserable specimen, the children said, all humps and hollows" (ibid, p. 6). But she often deals with him kindly and respectfully, and also she does not allow other characters to disgrace him. But more importantly, she even likes him sometimes when we read that, "till she [Mrs. Ramsay] gathered that he [Charles Tansley] had got back entire self-confidence, had recovered from the circusand was about (and now again she liked him warmly) to tell her" (ibid, p. 9). This affirms the dialogic discourse in the context in which everyone's opinion toward the others is unfinalized; sometimes characters, who detest each other, put away their hostility. Concerning unfinalizability, our behavior is never going to be fixed around just one anchor. According to Bakhtin:

There is neither a first nor last word and there are no limits to the dialogic context (it extends into the boundless past and the boundless future). Even past meanings, that is, those born in the dialogue of past centuries, can never be stable (finalized, ended once and for all) - they will always change (be renewed) in the process of subsequent, future development of the dialogue. At any moment in the development of the dialogue there are immense, boundless masses of forgotten contextual meanings, but at certain moments of the dialogue's subsequent development along the way they are recalled and reinvigorated in renewed form (in a new context). Nothing is absolutely dead: every meaning will have its homecoming festival. (1986, p.170)=

As a result of this mechanism in this novel, no final resolution comes to the fore to establish its logic in a state of doubt or disagreement, while this open-endedness paves the way for the partakers in dialogic discourses to tolerate each other. No word is going to be the final word which allows the dialogue to continue purposefully.

As another example, we can talk about the dinner party when Lily Briscoe nicely asks Mr. Tansley to take her to the lighthouse; "judging the turn in her mood correctly-that she was friendly to him now-he was relieved of his egotism, and told her how he had been thrown out of a boat when he was a baby; how his father used to fish him out with a boathook, that was how he had learned to swim" (Woolf, 1994, p. 67). This shows Mr. Tansley changing his attitude toward Lily temporarily and now he expresses his warm feelings by telling her his childhood memories. Even these two characters, that show a history of mainly negative interactions and opinions about each other, can get along sometimes which highlights the operation of unfinalizability in a dialogic discourse. The characters in this novel stand for different types of people in the society: Lily Briscoe incarnates an artist woman who perpetually tries to see life through the mirror of her professional products, Mr. Ramsay, a university professor who is not practical enough with life's problems, represents an intellectual living in the ivory tower of his alienation from his townspeople, Mrs. Ramsay, an elderly and kind mother and wife, materializes the modern communicative woman who successfully undertakes social duties also, and Charles Tansley symbolizes the unpopular guy who yet attempts to create a small but abundant society of different thoughts and tastes. These characters continue to show different new relationships while they never absolutely finalize their opinion and attitude toward the other people.

Inviting many people with different outlooks to a party, Mrs. Ramsay plays a crucial role to bring them together under a same roof. In the first chapter she assigns herself to create a situation where all of them feel they are her welcomed guests. As a result, none of them is forced to leave the party or to accept anyone else's ideas as a precondition to stay 
there. However, it seems that the guests do not really appreciate their hostess's efforts and just do whatever she expects them to do, which illustrates a policy of reluctant toleration. It is in the ground of her grace and tolerance that she can create a situation where there is mutual respect among the people with a variety of tastes and perspectives. Hence, we can consider Mrs. Ramsay as an agent of communication who keeps them connected to each other, especially when she plans for them to marry as a possibility for bringing them together in an idealized way.

Sometimes, she also plays the role of a negotiator among the characters. For example, when Cam and James Ramsay fight over the "horrid skull" (ibid, p. 83) (that is, as to if it should remain there with them and in their bed room), at first she tries to convince Cam that it is just a skull and there is nothing scary about it, but when she realizes that it is not helpful, she just says "we will cover it up" (ibid). What was annoying for Mrs. Ramsay in this case was the state of disagreement and dispute over this issue between her children along with the warlike environment that did not let her children go to sleep. We read that, "the children were not asleep. It was most annoying... there was James wide awake and Cam sitting bolt upright, and Mildred out of her bed in her bare feet" (ibid, p. 82). She does not wish to privilege any of her children although she doesn't like the skull on the first place. In other occasions, this hostile environment between her children is clearly observable- when we read that, "strife, divisions, differences of opinions, prejudices twisted into the very fibre of being, oh that they should begin so early, Mrs. Ramsay deplored. They were so critical, her children" (ibid, pp. 6-7). In this case the point is that her children can hold different thoughts as long as these thoughts are not problematic and they don't create a sense of critical prejudice among themselves. Mrs. Ramsay's efforts along with Woolf's narrative techniques help to spread a free play of diverse ideas inside different characters' consciousness which can be opposite to the others but they do not try to annihilate each other at least. As an example, Mr. Ramsay is not interested in Lily Briscoe's character but they do not "come upon each other [to engage in a hostile confrontation]" (ibid, p. 27). The fact that everybody in the novel has the privilege to preserve his or her individuality even if it goes counter the established ideology (like in the case of Charles Tansley) is a main feature of Woolf's work.

In the second chapter, when Mrs. Ramsay is dead, there is nothing but destruction which could symbolically stand for the clash of ideas that meant to establish a monologic discourse; as a result there is only war and annihilation. Monologue stands in opposition to dialogue where there is only one authoritative voice ruling over the discourse. We feel that the time of domestic life and gatherings is already gone, there is no longer a chance for dialogism, while the dark spirit of the "dragon", roaring around the house, perfectly objectifies this monologic force. In this chapter, we are aware that some characters pass away: one is killed in at war which is probably the best embodiment of the aftermath of monologism between nations (bits of this data are actually narrated at the beginning of the third chapter). When Mrs. Ramsay is no longer there, characters begin to realize her important role; "the house, the place, the morning, all seemed strange to her [Lily]. She had no attachment here, she felt no relations with it... as if the link that usually bound things together had been cut, and they floated up here, down there, off, anyhow" (ibid, p.110).

The first step in destroying dialogism in narrative is perhaps the creation of a hierarchical system in which something or somebody becomes a dominant authoritative ruling force. White states that, "monologism, according to Mikhail Bakhtin, represents the shutting down of dialogue and its alteric potential. For Bakhtin, and his followers, monologism exists where ultimate truth claims, as truth-istina, do not make room for alternative perspectives on truth, as truthpravada" $(2008$, p.1). If such a situation becomes permanent, there will be a chance of establishing a monologue in which there is only one ruling voice. Hence, to prevent the formation of such a hierarchical organization it is necessary to remain unfinalized within a dialogic discourse where no one has an absolutist finalized authority. It is a vital dimension of a dialogic discourse that everybody has a chance of self-declaration while it is of no significance who says the truth. White elaborates on this feature of narrative dialogism;

Building on the claim that monologism, left unchallenged, represents an attempt to shut down dialogue and freedom, Bakhtin offers an alternative route through his philosophy of dialogism. In dialogism there is always room for debate since inquiry is approached ontologically, emphasizing point-of-view rather than truth. (ibid, p. 3)

In Woolf's text-we realized that no character could be fully enough, known, because if in a certain moment they can hate each other, in a next occasion they may change their mind to show nice affections to one another. For example, in one occasion in Mrs. Ramsay's dinner party Lily Briscoe shows nice affections to Charles Tansley in response of which he shows a warmer attitude toward her. The characters' attitudes and their correspondence to the outside world are involved in an endless chain of formation and reformation. In Problems of Dostovovsky Poetics the Bakhtin asserts that:

The catharsis that finalizes Dostoevsky's novels might be - of course inadequately and somewhat rationalistically - expressed in this way: nothing conclusive has yet taken place in the world, the ultimate word of the world and about the world has not yet been spoken, the world is open and free, everything is still in the future and will always be in the future. (1984a, p.128)

If the characters cannot hold a fixed attitude toward each other, they cannot engage in a hierarchical system that puts them in stable positions. It is through this process of permutation that they ultimately become unfinalized, which in turn paves the way for dialogism. As an example, when Mr. Ramsay was afraid of being forgotten as an intellectual figure, "he showed his uneasiness quite clearly now by saying, with some irritation, that, anyone, Scott (or was it Shakespeare?) would last him his lifetime. He said it irritably" (Woolf, 1994, p.77-8); hence he kept changing his authoritative tone toward the others so that he would be milder and more dialogic both in manner and matter. 
In the last chapter, when the characters come together again under a single roof, they no longer strive to practice their previous self-oriented outlook in totalitarian ways, but have learned how to partake in partially dialogic negotiations to the benefit of mutual understanding through interactive interpretation. When Mr. Ramsay reminds it to Lily Briscoe that they've changed, we believe more fully in their efforts to improve. In addition, it is what Mrs. Ramsay has always asked them about. Although Mrs. Ramsay is no longer alive, no voice intends to suppress the others voices. The fact that all of them (except those who have died) are here again shows that they are consciously capable of tolerating each other. No character will submissively allow the opinions of any other character to be imposed on him/her. If they are arranging to take a visit to the lighthouse, it is because when Mrs. Ramsay was alive she insisted that they should take a visit there. When she was alive she had it in mind to gather the people there, therefore it can be said that (their voyage to) the lighthouse embodies the self of Mrs. Ramsay. Although not all the characters go there, their voyage there binds them together and gives them the collective purpose of learning how to come to terms with others for their mutual forbearance. This is what Mrs. Ramsay was decisively encouraging them to do; her purpose was to help make different characters to stay in discourse even if they had opposite ways of thinking.

When Mr. Ramsay finally starts chatting with Lily Briscoe, he is neither ironic nor sarcastic. In the novel we read, “'[Lily tells Mr. Ramsay] what beautiful boots?' she exclaimed... she knew, and she looked up expecting to get it, in one of his sudden roars of ill-temper, complete annihilation. Instead Mr. Ramsay smiled. His pall, his draperies his infirmities fell from him" (ibid, p.115). Mr. Ramsay and Lily finally succeeded in having a dialogue. Perhaps Mr. Ramsay and James have been hating each other more than any other characters in the whole novel, but near the very end they come to the point of mutual respect and finally father complements the son: "at last he [Mr. Ramsay] said triumphantly: 'well done!' James steered them like a born sailor” (ibid, p. 153). Actually, it is Mrs. Ramsay who has triggered this idea of mutual respect, and it is for her that Woolf's lighthouse of mutual understanding through dialogism is standing.

\subsection{Carnival}

An important element in the creation of a dialogic discourse in a novel is carnival, because, to speak for Kreshner again, "if dialogism is the novel's proper form, carnival underlies its optimal content; the true novel is carnivalized" (2001, p. 25). Carnival happens when a ruling person or an established hierarchy loses his/her/its power to a marginalized party which in turn causes the active participation of the marginalized party. It is here that Kreshner claims that, "carnival embodies a kind of folk wisdom that celebrates the body and opposes all forms of authority" (ibid). Although carnival celebrations are temporary, carnival actually launches objections against the monologic system while it is the realization of the notion of unfinalizability that no one could retain the highest position permanently. In Woolf's book, carnival can be traced as a kind of mild or indirect one because there, we cannot find any bold hierarchies in the Bakhtin's sense of the word. Therefore, it is in the inside of the novel's discourse that carnival actually resides. Mr. Ramsay, whose voice is potential to be a dominant voice, goes through a discourse which no longer allows him, directly or indirectly, to establish himself as an authoritative man. But his mental transcendence should mainly turn the scale because of his wife; it is mainly for his love and respect to her that hereafter he will prevent himself to impose his outlook upon the others.

Woolf prefers to solve the problem of Mr. Ramsay's bullying over James and others in a domestic manner. As an example, James is impatient about going to the lighthouse but Mr. Ramsay and Charles Tansley keep teasing him by insisting that the weather is going to be stormy. Mrs. Ramsay steps in to give hope to James which humiliates the previous negative statements about the stormy weather. But the boldest carnival scene perhaps happens at the dinner party where almost everybody expresses himself or herself freely and behaves as s/he wishes. Mr. Ramsay is no longer the sole dominant intellectual voice, because the story gives the chance to every character to freely talk his or her thoughts. Hence, the dinner party exemplifies a carnival in the literal sense of the word. People are happy there even however Mr. Ramsay does not like it; he cannot exert his authority there, and the context of the carnival forces him to consider his behavior as well. Nevertheless, one cannot find many examples of carnival in this novel although when it appears, it appears mainly in a carnivalesque narrative discourse. Their voyage to the lighthouse is the space of a carnivalesque discourse against Mr. Ramsay's initial refusals to go there. The carnivalesque narrative discourse can be traced in the last chapter, because as Mr. Ramsay doesn't any more bully the other people, his relations with them undergo radical changes; and as they become more dialogic, they become more sincere and more productive.

\section{Conclusion}

In To the Lighthouse, Virginia Woolf has created a story world in which a variety of characters come together to express themselves without being suppressed or made to change their ways of thinking. Her characters in this novel represent real citizens whose different tastes and social backgrounds guarantee the variety of the modern life. A real dimension of this representation of modernity is its radical dialogism which results in a polyphonic novel, because thanks to the differences of the individual people, dialogism privileges their individuality and preserves it. On the other hand, and in cooperation with dialogism, the carnivalesque narrative discourse in this novel privileges none of the characters to establish a hierarchical system for the suppression of other characters. Carnival is mainly created through preventing Mr. Ramsay from exerting his authoritative power over the others. At the end, Mr. Ramsay joins the dialogue and becomes the leader of those who head to the lighthouse. Mrs. Ramsay's role in bringing these people together is crucial in the formation of a dialogic discourse. Considering that she uses a trip as an excuse to bring them together in the lighthouse, the lighthouse stands for herself as an extension of compromise through mutual understanding and dialogic communication. The functioning of this dialogic narrative structure is guaranteed by an 
unfinalizability; characters' ways of thinking and behavior constantly change, and the person of the truth-teller is not important because the fact that no one on the scene should take the primary attention of the discourse. In this way, they learn how to tolerate each other and accept other's existence and rights.

\section{References}

Bakhtin, M.M. (1981). The Dialogic Imagination: Four Essays (C. Emerson and M. Holquist, Trans). Austen: University of Texas Press.

Bakhtin, M. M. (1984a). Problems of Dostoevsky's Poetics (C. Emerson, Trans.). Minneapolis: University of Minnesota Press.

Bakhtin, M. M. (1984b). Rabelais and His World (H. Iswolsky, Trans.). Bloomington: Indiana University Press.

Bakhtin, M. M. (1986). Speech Genres \& Other Late Essays (V.W. McGee, Trans. No. 8). Austin: University of Texas Press.

Dentith, S. (1995). Bakhtinian Thought: An Introductory Reader. London: Routledge Publication.

Freedman, S.W., \& Ball, A. (2004). Ideological Becoming: Bakhtinian Concepts to Guide the Study of Language, Literacy, and Learning. In Ball, A. \& Freedman, S.W. (Eds.). Bakhtinian Perspectives on Language, Literacy and Learning pp. 1- 33. New York: Cambridge University Press.

Holquist, M. (2002). Dialogism: Bakhtin and His World. London: Psychology Press.

Kershner, R.B. (2001). Mikhail Bakhtin and Bakhtinian Criticism. In Wolfreys, Julian (Ed.), Introducing Literary Theories: A Guide and Glossary pp. 19- 32. Edinburg: Edinburg University Press.

Mazzuchelli, P. G. (2009). The Rebellious Angel: Virginia Woolf, To the Lighthouse, and the Debate about Female Anger. Master's Theses, Dissertations and Graduate Research Overview. Paper 22.

Miller, L. C. (2011). Virginia Woolf 's Journey to the Lighthouse A hypertext essay exploring character development in Jacob's Room, Mrs. Dalloway, and To the Lighthouse. University of Tennessee Honors Thesis Projects. http://trace.tennessee.edu/utk_chanhonoproj/1463

Nodeh, S. (2013). Dialogic Narrative Discourse in Austen's Emma: A Bakhtinian Review. Kata, 15(1), 1-8. Retrieved last in July 2014, from http://puslit2.petra.ac.id/ejournal/index.php/ing/article/view/18739

Thomas, B. (2007). Dialogue. In Herman, David (Ed.). The Cambridge Companion to Narrative (pp.80-93). NY: Cambridge University Press.

Vaagan, R. W. (2007). Open Access scientific, electronic publishing and Bakhtinian dialogism. Papers in Communication and Culture, . 4(2), 85-99.

White, E.J. (2008). Bakhtinian dialogism: A philosophical and methodological route to dialogue and difference? Annual Conference of the Philosophy of Education Society of Australasia, 38.

Woolf, V. (1994). To the Lighthouse. London: Wordsworth Classics. 